JOLANTA MILUSKA

\author{
$\stackrel{\odot}{\|}$

\section{POGRANICZE W ŻYCIU JEDNOSTKI I GRUP SPOŁECZNYCH - FAKTY I KONTROWERSJE}

\begin{abstract}
Jolanta Miluska, Pogranicze w życiu jednostki i grup społecznych - fakty $i$ kontrowersje [Borderland in the life of individual and social groups: the facts and controversies] edited by A. Jasielska, M. Obrębska ", Człowiek i Społeczeństwo" vol. XLV: Oblicza współczesności. Perspektywa psychologiczna [Faces of modernity. A psychological perspective], Poznań 2018, pp. 47-66, Adam Mickiewicz University. Faculty of Social Sciences Press. ISSN 0239-3271.
\end{abstract}

Borderland may be understand in the various ways. Especially important is the conception of the territorially borderland. The article contains its definitions and characteristics in the correlation with the function of border and trans-borderland. The review of research connected with the identity of borderland's man and the influence of the borderland on its inhabitants (borderland "effect") shows its incoherent. Author postulates the program of the further research.

Jolanta Miluska, Instytut Psychologii Uniwersytetu Szczecińskiego, ul. Krakowska 69, 71-017 Szczecin, e-mail: jmiluska@amu.edu.pl

\title{
Wprowadzenie
}

Pogranicze jest terminem uniwersalnym, stosowanym przez przedstawicieli różnych dyscyplin naukowych, najczęściej psychologów, pedagogów, socjologów, historyków, geografów czy politologów. Jest też pojęciem 
obiegowym, wyrażającym intuicję dotyczącą czegoś „pomiędzy”. Orientacja ponowoczesna w humanistyce, rozmywająca granice i koncentrująca się na tym, co nieokreślone, wydaje się znaczną wagę przypisywać właśnie pograniczu. Także procesy globalizacji zmieniają rozumienie i funkcje obszarów wcześniej uważanych za centralne i peryferyczne. W tym kontekście pojawia się problem realnego znaczenia pogranicza dla jednostki, grup społecznych i całych społeczeństw. Jaki, w zależności od jego rozumienia, status przypisuje osobie i w jaki sposób wpływa na funkcjonowanie ludzi - to podstawowe kwestie, do których powinna się odnieść także psychologia. Czy na przykład pogranicze jako szczególny obszar stwarza warunki do wykreowania wybitnych osobowości, czy raczej sprzyja konfliktom wynikającym z różnic kulturowych? Czy jest dobrem społecznym czy raczej obszarem („,ziemią”) niczyją, niezagospodarowaną pod żadnym względem? Celem analizy jest ustosunkowanie się do problemu wpływu pogranicza na życie zamieszkujących je jednostek i grup społecznych.

Asumpt do myślenia na ten temat daje psychologiczne rozumienie pogranicza jako styku (bliskości) normy i patologii. Chodzi tu o oddzielenie poziomu cech i zachowań uznanych za zgodne z normą i tych znajdujących się poza nią (np. pograniczny poziom rozwoju intelektualnego). Szerszą wykładnię zagadnienia można znaleźć w koncepcji osobowości z pogranicza (borderline), będącą jednym z podtypów zaburzenia osobowości (Goldstein, 2003; Linehan, 2007). Termin ten wprowadził Robert Knight w połowie XX w. na określenie takich osób, których zaburzenia psychiczne mieściły się pomiędzy zaburzeniami psychotycznymi (schizofrenicznymi) a zaburzeniami neurotycznymi (nerwicami). Najbardziej typowe dla osobowości borderline objawy, takie jak niezwykle silne pragnienie bardzo bliskiej, wyłącznej relacji z drugą osobą i jednoczesny lęk, a także silne napięcie emocjonalne, prowadzą do znacznego pogorszenia funkcjonowania społecznego, zawodowego i do subiektywnego złego samopoczucia. Jednocześnie unika się uważania zaburzeń osobowości za choroby, gdyż sama osobowość steruje procesami radzenia sobie. Per analogiam można przyjąć, że każde pogranicze kryje w sobie pewien potencjał destrukcji i rozwoju. Dotyczyć to może także najbardziej znanego w naukach społecznych sposobu rozumienia pogranicza jako specyficznego terytorium. Prezentacja poglądów na temat jego istoty, cech i funkcji pozwala dalej odnieść się do wpływu pogranicza na sposób myślenia, oceniania i zachowanie jego mieszkańców. 


\section{Pogranicze terytorialne: rozumienie zjawiska}

Najbardziej powszechne rozumienie pogranicza odnosi się do jego terytorialnego (geograficznego) ujęcia, choć podejście to bywa krytykowane i traktowane jako oznaka osiągnięcia przez naukę (socjologię) pewnej teoretycznej stabilizacji, lub nawet skłonność do teoretycznego zamykania się (Babiński, 2005). Znawca zagadnienia, Andrzej Sadowski, podkreśla wagę terytorialnego (przestrzennego) aspektu pogranicza, definiując je jako obszar położony przy granicy lub daleko od centrum (tu kategoria „pogranicze” staje się bliskie kategorii „peryferia”) lub inaczej - obszar wyróżniony w obrębie większej całości (państwo, region, środowisko (Sadowski, 1995). Tradycyjnego rozumienia pogranicza nie unika także Grzegorz Babiński, według którego jest to „mniej lub bardziej określony, w pewnym stopniu historycznie zmienny obszar” przenikania się grup etnicznych (Babiński, 1994, s. 6), a także Antonina Kłoskowska, której zdaniem pogranicze to „terytorium położone między dwoma obszarami państwowymi lub regionalnymi, charakteryzujące się przemieszaniem etnicznym lub narodowościowym wynikającym z bliskości przestrzennej” (Kłoskowska, 1996, s. 125).

Terytorialne rozumienie pogranicza uległo stopniowemu poszerzeniu, nowe definicje i koncepcje zdecydowanie rozwijają ten koncept. Sadowski poszerzył swoją wcześniejszą koncepcję, wprowadzając kilka autonomicznych kategorii odnoszących się do pogranicza i tworzących ważne obszary badań: społeczny obszar pogranicza, więź terytorialna mieszkańców, pograniczność jako kategoria służąca do określania całokształtu kontaktów międzykulturowych dokonujących się na obszarze pogranicza oraz pogranicze społeczne lub społeczno-kulturowe jako określona postać ładu ukształtowanego w następstwie realizowanej pograniczności (Sadowski, 2008a). Autor eksploruje pograniczność, która dotyczy przekraczania granic usytuowanych na społecznym obszarze pogranicza. Jest więc „pograniczność [...] dynamicznym wymiarem pogranicza, jest przejawem wielości wysiłków jednostkowych i zbiorowych, skierowanych na przekraczanie granic, na poznanie innych w połączeniu z tworzeniem koniecznych ku temu warunków instytucjonalnych” (Sadowski, 2008a, s. 22). Koncepcję tę uzupełnia zjawisko transgranicza, które dotyczy obszarów położonych po obu (kilku) stronach granic administracyjno-państwowych (politycznych) oraz transgraniczność, która zawiera się w szerszym znaczeniowo pojęciu 
transgranicza (Sadowski, 2008a) i oznacza proces przenikania przez granice ludzi, ich wytworów, wartości itd. (Golka, 1999). Nie każde wszakże przenikanie przez granice spełnia wymóg transgraniczności. Ważne jest to, aby przepływy te miały charakter masowy i trwały, dokonywały się na podstawie wspólnego prawa, zasad moralnych, obyczajowych i religijnych; powinny one także być wspierane przez społeczeństwa sąsiadujących państw. Ważne jest też, aby wytworzyła się sieć organizacyjna kontaktów transgranicznych w postaci wielości instytucji i organizacji, których działanie sprzyja stworzeniu pewnego ładu organizacyjnego na obszarach pogranicza (Sadowski, 2008a, s. 25). Pomysł na powiązanie ze sobą pogranicza i transgranicza oraz zachodzących na nich procesów, wskazanie podobieństw i różnic, złożoności i zależności między nimi nie tylko inspiruje nowe badania, ale też pokazuje, że problematyka pogranicza jest z istoty rzeczy interdyscyplinarna.

Granica - pojęcie ściśle związane z pograniczem - to linia zamykająca lub oddzielająca pewien określony obszar, np. terytorium jednego państwa, od innych. Tu, podobnie jak wcześniej, eksponuje się fizykalny, odniesiony do przestrzeni wymiar granicy, któremu może towarzyszyć wymiar świadomościowy (Opioła, 2014), równie ważny dla sposobu zachowania ludzi (np. przekonanie o niedostępności tego, co za granicą, szczególna atrakcyjność takich przedmiotów). Geograficzne granice, dzieląc państwa i narody, stają się oczywistym wskaźnikiem politycznych granic i obszarów. Granica jako linia demarkacyjna zapewnienia suwerenność państwa i względnie stabilne przywiązanie społeczeństwa do danego terytorium.

Specyfika granicy decyduje w dużej mierze o charakterze pogranicza. Józef Chlebowczyk (1983) wyróżnia dwa jego rodzaje: pogranicza stykowe, czyli obszary współżycia grup wyraźnie odrębnych, np. Słowaków i Węgrów, oraz pogranicza przejściowe, zamieszkiwane przez społeczności pokrewne pod względem językowo-etnicznym, jak Serbowie i Chorwaci, gdzie brak jest wyraźnej linii demarkacyjnej. Na rodzaj granicy wskazuje też w swojej koncepcji starego i nowego pogranicza Babiński (2001). To pierwsze wiąże się z granicami luźniejszymi, podlegającymi łatwemu przenikaniu wpływów (pogranicze raczej przejściowe, o znacznym zakresie przenikania kultur, o płynnym zróżnicowaniu ekonomicznym i społecznym), to drugie natomiast posiada granice restryktywne (pogranicze raczej stykowe, o wyraźnych granicach terytorialnych i kulturowych, z dużymi dystansami cywilizacyjnymi między zamieszkującymi je zbiorowościami).

Jak widać, rodzaj granicy i pogranicza kształtuje w dużym stopniu relacje społeczne. Marian Golka (2004), korzystając z metafor, opisuje pięć modeli granic i określonych przez nie stosunków między ludźmi: (1) granica jako 
„linia okopów” - między stronami nie ma żadnej współpracy, a przenikanie jest nieznaczne; (2) granica jako „rzeka” - dzieli strony w sposób pasywny: przeciwnicy wiedzą o swoim istnieniu, ale nie mają możliwości wywołania otwartego konfliktu, przeszkadza w tym nie tylko fizyczna granica, ale też obecność siły nadrzędnej; (3) granica jako „ściana” - jest wyrazem segregacji lub izolacji jawnej bądź skrywanej: strony mają świadomość odrębności, pragną jednak uniknąć konfliktów przez zachowanie izolacji; (4) granica jako „parkan” - oddzielenie symboliczne - strony przyzwyczaiły się do swojego istnienia, znają się dobrze; (5) granica jako „ulica” - mało wyrazista, obie strony uznają pewne prawo do przebywania na niej, granica bardziej łączy niż dzieli.

Tego rodzaju koncepcje wyrażają przekonanie o potrzebie istnienia i oczywistości granic stanowiących element pogranicza. A jednak obserwuje się proces deterytorializacji, która oznacza zanikanie granic, osłabnięcie związku między władzą, kulturą i miejscem (Deleuze i Guattari, 1994). Zygmunt Bauman (2002) określa tę sytuację jako symboliczny koniec ery przestrzeni. Istnieje wszak przeciwstawny proces - reterytorializacji, który oznacza, że władza związana z terytorium trwa i jest reorganizowana (Deleuze i Guattari, 1994). Może to być jedna z reakcji na skutki wdrażania projektów typu Schengen, a więc Europy bez granic. Jan Zielonka, odnosząc się w pracy Kontrrewolucja. Liberalna Europa w odwrocie między innymi do współczesnej funkcji granic, pisze, że wezwanie do stworzenia Europy pozbawionej granic może prowadzić do chaosu i anarchii, choć jednocześnie zamknięcie granic i ograniczenie migracji jest praktycznie niemożliwe bez pogorszenia funkcjonowania pewnych ważnych gałęzi gospodarki. Rozwiązaniem tego dylematu jest negocjacja skali przenikania się wpływów ponad granicami. Szczelność granic da się stopniować i w efekcie suwerenność państwa jest także stopniowalna. Można zatem postulować rozsądne zarządzanie otwartością na wpływy polityczne, gospodarcze czy obyczajowe, a granice chroniące społeczeństwa powinny być półprzepuszczalne. Otwartość nie powinna zatem funkcjonować jako dogmat, ale źródło pożądanych zmian społecznych (Zielonka, 2018). Tego rodzaju polityka powinna także wpływać na życie na pograniczu.

Pogranicze niewątpliwie wpływa na funkcjonowanie ludzi je zamieszkujących, choć np. Leszek Gołdyka twierdzi, że nie ma przekonujących dowodów na istnienie „efektu” pogranicza, albowiem brakuje badań porównawczych i podłużnych, a stosowane narzędzia badawcze (głównie kwestionariuszowe) nie są odpowiednim sposobem jego określenia. Trudno też oddzielić od siebie „wyjaśnianie pogranicza”, a więc diagnozowanie jego 
właściwości społeczno-kulturowych, i „wyjaśnianie pograniczem”, a więc stwierdzenie, że właściwości pogranicza warunkują przebieg socjalizacji jego mieszkańców, a także inne procesy i charakter zjawisk społecznych na nim obserwowanych (Gołdyka, 2016). Mimo sceptycyzmu autora można jednak wskazać pewne różnice między ludźmi z pogranicza i spoza niego.

\section{Pogranicze a tożsamość jego mieszkańców}

Badania nad pograniczem koncentrują się w istotnym zakresie na problemie tożsamości oraz postaw i zachowań zamieszkujących je ludzi, a więc kwestiach bliskich nie tylko socjologii, ale przede wszystkim psychologii. Ich prezentacja pozwala zatem wskazać psychologiczną perspektywę w opisie i interpretacji obserwowanych zjawisk i procesów.

Jerzy Nikitorowicz jest zwolennikiem myślenia o pozytywnym dla tożsamości jednostki ( $w$ wymiarze indywidualnym, kulturowym i międzykulturowym) znaczeniu życia na pograniczu, gdzie ścierają się wpływy wielu kultur, religii i społeczności. W swojej koncepcji tożsamości człowieka pogranicza (Nikitorowicz, 1995) zwraca uwagę na umiejętność wychodzenia poza tożsamość narodową i proces kreowania tożsamości ponadnarodowej, bez utraty tej pierwszej, co odpowiada za jej nieskończoność, wielowariantowość i dynamikę. Nie jest to tożsamość przypisana, ale osobiście wypracowany w procesie negocjacji społecznych projekt świadomości indywidualnej (Nikitorowicz, 2016, s. 35). O bogactwie tożsamości człowieka pogranicza decyduje to, że uczestniczy on „w niekończącym się procesie komunikacji, w przejściu od reakcji na inność do interakcji z nią, od monologu do dialogu kultur, od dominacji stereotypów i uprzedzeń do wzajemnego zrozumienia, negocjacji i dbałości o wspólny spadek kultur pogranicza” (Nikitorowicz, 2016, s. 37). Przykładem takich bujnych, wielowymiarowych tożsamości wypracowanych na pograniczu kultury Zachodu i dziedzictwa Wschodu mogą być postaci: Ludwika Zamenhofa, Czesława Miłosza, Janusza Korczaka czy Isaaca Bashevisa Singera. Co więcej, podleganie wpływom łacińskiej i bizantyjskiej cywilizacji może odpowiadać nie tylko za kulturowy pluralizm, wysoki poziom religijnej i etnicznej tolerancji i dominantę tożsamości lokalnej ludzi z pogranicza, obserwowaną na przykład wśród Białorusinów, ale też sprzyjać ukonstytuowaniu się nie tyle cywilizacji peryferii, ile subcywilizacji pogranicza, zawierającej wszystkie potrzebne atrybuty, takie jak swoista kultura, wartości, historia i narodowe oraz kulturowe wspólnoty (Titarenko, 2009). 
Podobnie postrzega człowieka pogranicza Sadowski, który przypisuje mu specyficzną świadomość społeczną i tożsamość. Obserwując pogranicze litewsko-polsko-białoruskie, stwierdza, że żyją tu szczególne typy mieszkańców posiadający świadomość przynależności do różnych kultur (Sadowski, 1992). Cechuje ich: lokalna mobilność, dominacja lokalnej, regionalnej tożsamości, znajomość różnych języków (przede wszystkim sąsiadów), otwartość na kulturową różnorodność, traktowanie odmienności jako normy życia codziennego i wyższy niż na innych terenach poziom tolerancji dla różnych rodzajów odmienności (Nikiforova, 2010). „Człowiek pogranicza” to „człowiek nowy”, inny od istniejącego wcześniej, taki, który podziela życie kulturalne i tradycje dwóch lub więcej różnych społeczności (Sadowski, 1995). Natomiast Zbigniew Kurcz (2008) widzi człowieka pogranicza jako kogoś innego, w sensie kogoś, kto odbiega od przeciętności, jest niestandardowy, nieprzeciętny. Podobnie myślą o człowieku pogranicza inni autorzy, formułujący swoje wnioski w odniesieniu do mieszkańców Podlasia (Mironowicz, 1992; Plit, 2014). Jest zatem „człowiek pogranicza” osobą tolerancyjną, wielokulturową, używa różnych języków czy dialektów, do jego rodziny i grona przyjaciół należą ludzie reprezentujący odmienne narodowości i kultury, często ma poczucie należenia do dwóch narodów i kultur, uczestniczy w świętach, obrządkach i respektuje zwyczaje różnych społeczności, jest też silnie przywiązany do regionu, który traktuje jak swoją „małą ojczyznę”. Cechy te, związane z wielowiekową tradycją kohabitacji różnych społeczności, sprzyjają brakowi konfliktów w czasach, gdy w Europie narastają tendencje nacjonalistyczne, separatystyczne i odżywają historyczne konflikty. Koncepcje te wskazują na możliwy efekt pogranicza w postaci wykreowania człowieka nieprzeciętnego, prezentującego nowe, innowacyjne postawy, tolerancyjnego i otwartego na nowe doświadczenia. Zdaniem Gołdyki „człowiek pogranicza” to przede wszystkim konstrukt poznawczo-aksjologiczny, ktoś, kogo - jako „efekty” pogranicza - cechują „określone sposoby spostrzegania społecznego (rejestrowania, identyfikowania, interpretowania, wartościowania) „swoich” i „obcych” (Gołdyka, 2016, s. 17).

Powyższe koncepcje, oparte bardziej na danych obserwacyjnych niż wynikach badań przeprowadzonych z użyciem wystandaryzowanych narzędzi badawczych, wymagają na pewno empirycznej weryfikacji. Skłaniają do tego choćby rezultaty badań dowodzących problemów z utworzeniem tożsamości grupowej (społecznej) mieszkańców regionów, a do takich można zaliczyć pogranicze. Zasadne tu pojęcie tożsamości regionalnej może być zdefiniowane jako szczególny rodzaj „tożsamości społecznej (zbiorowej) i kulturowej, opartej zarazem na tradycji regionalnej (lokalnej), odnoszonej do wyraźnie 
zdefiniowanego i delimitowanego terytorium regionu (miejsca), jego specyficznych cech społecznych, kulturowych (symbolicznych), gospodarczych czy nawet topograficznych, wyróżniających go spośród innych regionów (miejsc)” (Szczepański i Śliz, 2010, s. 2). Jest tożsamość regionalna „zbiorową, społeczną i indywidualną identyfikacją z regionem i jego poszczególnymi zbiorowościami, ich systemami społeczno-kulturowymi, zajmowanymi terytoriami, przestrzeniami i wreszcie miejscami” (Szczepański i Śliz, 2010, s. 3). Poglądy na temat realności i rangi tej tożsamości są jednak zróżnicowane.

Bożena Domagała (1996) twierdzi, że wśród mieszkańców pogranicza obserwuje się niski poziom świadomości lokalnej czy regionalnej, niepozwalający na utworzenie odpowiedniej tożsamości. Może to mieć związek właśnie ze specyfiką jego granic, które są mniej zamknięte niż na przykład miasto czy kraj. Z tego względu region nie może być i - jak wskazują wyniki badań - nie jest obiektem silnego doświadczenia i identyfikacji większości ludzi (Bartkowski, 2003). Tożsamość regionalna okazuje się słabsza niż narodowa i miejska. Takie regiony Polski, jak Mazowsze, Małopolska, Pomorze czy Dolny Śląsk mają dla większości ich mieszkańców mniejsze znaczenie niż konkretne miejscowości czy cała Polska (badania zespołu Marii Lewickiej (2012)). Dramatyczna historia pewnych regionów czy względy polityczne mogą wprawdzie odpowiadać za silny związek emocjonalny z nimi i utrwalać tożsamość ich mieszkańców (dotyczy to polskich Kresów Wschodnich czy Opolszczyzny z jej tendencjami do uzyskania autonomii), są to jednak sytuacje wyjątkowe. Większość wyników badań dotyczących tożsamości regionalnej wskazuje bowiem generalnie na słabość identyfikacji $\mathrm{z}$ regionem. W sondażu International Social Survey Programme przeprowadzonym w roku 1995 w 24 krajach najsilniejsze przywiązanie respondentów stwierdzono do własnego kraju, a najsłabsze - do kontynentu. Region uzyskiwał najczęściej czwartą rangę, po „sąsiedztwie” i „mieście” (Laczko, 2005). Podobnych wyników dostarczają przeprowadzone przeze mnie badania (Miluska, 2007), które wskazują, że tożsamość lokalna (miasto/wieś lub region) ma mniejsze znaczenie niż inne jej postaci. W procedurze rangowania tożsamość lokalna zajmowała szóstą pozycję, po tożsamości rodzinnej, płciowej, narodowej, zawodowej i religijnej, wyprzedzając tożsamość europejską, osobistą, polityczną i kosmopolityczną. Mateusz Stopa (2008), który badał identyfikacje z regionem na Podkarpaciu, stwierdził, że region jest kategorią podporządkowaną podstawowym dla badanych identyfikacjom etnicznym i lokalnym i często traktowaną instrumentalnie. Ostatnie badania na polskiej próbie reprezentatywnej (Kowalczuk, 2015) wskazują jednak na zmianę znaczenia, a więc i identyfikacji z miejscem zamieszkania: 
miejscowość okazuje się dla badanych ważniejszym obiektem niż kraj, który zajmuje w rankingu drugą pozycję. Miejsce trzecie przysługuje regionowi. Być może dzieje się to za sprawą konfliktów społeczno-politycznych, dzielących istotnie polskich obywateli i koncentrujących uwagę na najbliższych i bardziej przyjaznych miejscach. Jednocześnie konflikty te mogą sprzyjać podkreślaniu tożsamości narodowej, na co wskazują z kolei badania Marii Górkiewicz i Zdzisława Kroplewskiego (2016) prowadzone wśród mieszkańców Szczecina. Dowodzą one większego znaczenia tożsamości narodowo-konserwatywnej w stosunku do tożsamości lokalnej i europejskiej we wszystkich grupach wiekowych (16-20, 40-50 i 65-80 lat). Jednocześnie poziom tożsamości lokalnej jest najniższy w grupie najmłodszych osób badanych, a najwyższy wśród najstarszych, których cechuje także najwyższy poziom przywiązania tradycyjnego („miejsce zastane”), przywiązania ideologicznego („miejsce odkryte” - Hummon, 1992) oraz skala wiedzy o Szczecinie (tu najsłabiej prezentuje się młodzież). Ciekawych wyników dostarczają też badania Marii Zielińskiej (2007) dotyczące wyznaczników polskości (cechy tzw. prawdziwego Polaka). Autorka stwierdziła, że badani Lubuszanie, a więc mieszkańcy zachodniego pogranicza Polski, cechują się większym niż mieszkańcy centralnych województw przywiązaniem do tradycyjnie rozumianych wyznaczników polskości (Zielińska, 2007, s. 260). Bardziej intensywny koncept tej tożsamości wykazały osoby starsze, o wyższym statusie zawodowym, wyższej religijności i popierające tzw. paternalizm państwowy (zbliżony do funkcji państwa opiekuńczego). Takie zależności nie wystąpiły na terenach centralnych. Różnorodność tych wyników wskazuje, że badania dotyczące rangi tożsamości regionalnej (i lokalnej), w kontekście innych rodzajów tożsamości, uwzględniające liczne charakterystyki osób badanych (ważna historia ich rodzin) i sytuacji społeczno-politycznej wymagają stałej weryfikacji.

Przykłady koncepcji i badań dotyczących tożsamości mieszkańców pogranicza wspieranych badaniami dotyczącymi rangi tożsamości regionalnej w szerszej populacji czynią stale otwartym pytanie o specyfikę tej tożsamości, zarówno jeśli chodzi o jej treść (jakie przekonania, emocje, oceny ją tworzą), jak i strukturę (jak te elementy są scalone). Co zatem oznacza „być mieszkańcem pogranicza”? Czy chodzi o tożsamość lokalną określaną jako „tutejsi”, która łączy wielowiekowe doświadczenia wieloetnicznych, wielokulturowych i wieloreligijnych wspólnot? Na taką możliwość wskazuje Larissa Titarenko (2009), według której na pograniczu polsko-litewsko-białoruskim tworzy się szczególna cywilizacja pogranicza, gdzie tożsamość lokalna dominuje nad narodową i etniczną identyfikacją. Czy dominuje tożsamość dziedziczona 
(etniczna), zintegrowana (społeczno-osobowo-kulturowa) czy raczej tożsamość rozproszona (wielokulturowa) (Nikitorowicz, 2003)? Ta pierwsza jest efektem zanurzenia jednostki w kulturze danej grupy i pierwotnej socjalizacji, która wpisuje jednostkę w grupę i wskazuje na wspólnotę pochodzenia. Ten rodzaj tożsamości odpowiada za podobny sposób rozumowania, przeżywania i zachowywania się. Jeśli tożsamość etniczna dominuje nad osobistą, może doprowadzić do dyskryminacji innych, do słabego wykształcenia się indywidualizmu na rzecz konformizmu. Tożsamość zintegrowana z kolei oznacza rezygnację z wąskiej etnocentrycznej perspektywy socjalizowania i kulturalizowania człowieka na rzecz jego indywidualizmu i odpowiedzialności, wspierania jego siły i potencjału. Istotą tej tożsamości jest jasność tego, kim się jest, pomimo zachodzących zmian wewnętrznych i środowiskowych. Wolność i aktywność takiej jednostki oznacza możliwość zaistnienia zmiany społecznej, a styl jej życia, twórczość i innowacyjność traktuje się jako istotne dla kreowania wartości i więzi w społeczeństwie (otwartość na inne kultury, odrzucenie metakultury i monokultury). A może dominuje tożsamość rozproszona (wielokulturowa), która oznacza wiedzę i świadomość jednostki, że należy ona do wielu grup społeczno-kulturowych wraz z emocjonalnym i wartościującym znaczeniem, jakie ma dla niej ta przynależność? Istotą tej tożsamości jest ustawiczna mobilność, otwartość i zmienność. O możliwości wykreowania takiej tożsamości świadczą wyniki badań Marka Barwińskiego (2017) prowadzone na Podlasiu. Spośród ponad 39 tys. osób określających siebie w roku 2011 jako Białorusini, ponad 12 tys. deklarowało białoruską tożsamość połączoną z inną, zwykle polską, często wskazywaną jako pierwsza. Jednocześnie należy wspomnieć o obserwowanym spadku liczby osób z identyfikacją białoruską: w latach 2002-2011 zmalała ona z 46420 do 39105 osób, a towarzyszy temu spadek częstości codziennego używania języka białoruskiego (stosuje go w codziennych kontaktach $65,2 \%$ badanych). Intensywność ewentualnego procesu powszechnej asymilacji kulturowej mniejszości narodowych na pograniczu może zminimalizować kwestię wielokulturowej tożsamości i osłabić rolę tego problemu w badaniach naukowych.

Jeśli jednak przyjąć stałe istnienie złożonej tożsamości mieszkańców pogranicza, to konieczne jest ustalenie, czy struktura tej tożsamości jest wewnętrznie jednoznaczna i spójna, czy też przybiera charakter tożsamości hybrydowej, będącej efektem mieszania się i krzyżowania różnych kultur (lokalnej, regionalnej, etnicznej, narodowej) w warunkach złożonych relacji, wpływu ukształtowanych i sąsiadujących ze sobą narodowości, a nawet forsowanych praktyk politycznych. W jaki sposób mieszkańcy zróżnicowanego kulturowo pogranicza radzą sobie z wielością kulturowych wzorów? 
W jaki sposób są w człowieku uporządkowane liczne kultury? Możliwym rozwiązaniem jest ich korelacja z różnymi wymiarami tożsamości i na przykład uznanie obywatelstwa, a więc formalna identyfikacja z kulturą większości („Jestem Polakiem”), i jednocześnie silny emocjonalny związek z kulturą grupy pochodzenia („Jestem Ukraińcem”).

\section{Pogranicze a postawy i zachowania jego mieszkańców}

Czy i w jaki sposób region wpływa na postawy i zachowania zasiedlających go ludzi? Badania socjologiczne i politologiczne dotyczące mieszkańców Ziem Odzyskanych, a więc regionów pogranicznych, w porównaniu do mieszkańców terenów o dłuższej historii związku z Polską, wskazują na szczególne ich funkcjonowanie społeczne i polityczne. Na przykład w wyborach po roku 1989 zaobserwowano bardzo słabą frekwencję wyborczą w województwie warmińsko-mazurskim, zachodniopomorskim i lubuskim. Mieszkańcy zachodu i północy Polski preferują partie lewicowe lub liberalne. Konserwatywny południowy wschód popiera raczej postawy prawicowe, podczas gdy północny-zachód optuje za podejściem liberalnym czy lewicowym. Jest to podział wyrażający silne różnice polityczne i emocjonalne, który można wyjaśnić, odwołując się do historii tych obszarów. Jej znaczenie wskazuje hipoteza „zaborowa”, która dotyczy sytuacji mieszkańców ziem polskich znajdujących się pod jurysdykcją trzech mocarstw zaborczych w latach 1795-1918. Polityka prowadzona przez te państwa mogła wytworzyć różne wzorce kultury politycznej i odmienne orientacje światopoglądowe. Proces tworzenia tych standardów determinowany był przez stosunek zaborców do ludności polskiej i Kościoła katolickiego oraz poziom rozwoju ekonomicznego i kulturalnego. Wzorce te usystematyzowane w całość za pomocą tradycji przekazywanej z pokolenia na pokolenie utrwaliły się na niektórych terenach i wpływają na postawy wyborcze (Raciborski, 1997). Ważna jest też historia powojenna. Preferencje polityczne i zachowania wyborcze mieszkańców Ziem Odzyskanych, a więc w dużej mierze pogranicznych, tłumaczy się masowymi powojennymi migracjami, które zerwały ciągłość kulturową i jednocześnie, mimo upływu lat, nie przyczyniły się do wytworzenia nowej stabilnej wspólnoty. Na nowych terenach powstało natomiast społeczeństwo z jednej strony zdezorientowane, pozbawione tradycji, bez cech wiejskich (Sakson, 1996), a z drugiej - łatwo przyjmujące nowe poglądy, potrafiące się dostosować do nowej rzeczywistości czy ustroju. Elementem zerwanej tradycji kulturowej jest stosunek do Kościoła katolickiego i skala praktyk 
religijnych. Najrzadziej praktyki religijne uwidaczniają się u obywateli województwa mazowieckiego, kujawsko-pomorskiego, pomorskiego i zachodniopomorskiego, a także lubuskiego (Marzec, 2010). Te dwa ostatnie to Ziemie Odzyskane i jednocześnie pograniczne regiony Polski. Udowodniono powiązanie między intensywnością praktyk religijnych a postrzeganiem wyborów. Uczestnictwo religijne odpowiada też za większe zainteresowanie sprawami lokalnymi (Turska-Kawa, 2011). Związek regionu ze specyficznym podejściem do Kościoła wyjaśniać ma też hipoteza zaborowa (Marzec, 2010).

Ważnym problemem jest określenie doświadczenia społeczno-kulturowego wykluczenia innych i siebie (Leontidou, Donnan i Afouxenidas, 2005) zarówno w relacjach z sąsiadami zza granicy, jak i w stosunku do centrum. Wiąże się to z szerszym problemem relacji między grupą większościową i mniejszościową (mniejszości narodowe, etniczne i religijne) i warunkami ujawniania tożsamości tej ostatniej, a także możliwymi tendencjami zmian w tym zakresie. Sadowski uważa, że w zależności od rodzaju polityki państwa, zauważanych typów relacji między mniejszościami narodowymi oraz związków (postaw) mieszkańców pogranicza z mniejszościami i większościami narodowymi, mniejszości mogą wybrać jeden z następujących statusów: separacja i wewnętrzna konsolidacja, integracja z otaczającą większością, integracja z narodem w „zagranicznej ojczyźnie” lub rozproszenie, dywersyfikacja (Sadowski, 2008b).

Dla zrozumienia relacji społecznych na pograniczu ważna jest analiza funkcji granic, ważnych dla jego specyfiki, co widać szczególnie w przypadku zachodniej granicy Polski po ustanowieniu naszego członkostwa w Unii Europejskiej. Radykalne ograniczenie ochronnej roli granicy (zapisy z Schengen), wbrew założeniom o pokojowej i kulturotwórczej roli tego zabiegu (niwelowanie różnic cywilizacyjnych, „ubogacenie” kulturowe), nie tylko nie zmniejszyły, ale raczej zwiększyły poziom lęku o suwerenność i spowodowały nasilenie rangi tożsamości narodowej, co może dalej uruchamiać wzajemne negatywne stereotypy i uprzedzenia. W taki sposób można interpretować przedstawione wcześniej badania Górkiewicz i Kroplewskiego (2016). Ta tendencja odzwierciedla wcześniejsze negatywne aspekty postaw wobec Niemców, na co wskazują badania Andrzeja Saksona (2003). Jeszcze przed wejściem Polski do Unii Europejskiej wśród Polaków mieszkających na pograniczu polsko-niemieckim obserwowano silne obawy dotyczące przejmowania ziemi, czy szerzej - majątku narodowego, co przemawia za tym, że Niemcy byli postrzegani w kategoriach zagrożenia. Późniejsze badania dowodzą jednak pewnej ewolucji tej postawy: być może właśnie za sprawą rozszczelnienia granicy zachodniej dla mieszkańców polskiej części 
euroregionu Nysa niemieckość oznacza raczej inność niż obcość (Dębicki i Doliński, 2011). Niekonkluzywność tych badań wskazuje na potrzebę stałego kontrolowania wzajemnych postaw w zmieniających się warunkach społeczno-politycznych. Psychologia wskazuje pewną podstawę uwarunkowań rodzaju tych relacji, którą jest hipoteza kontaktu, zakładająca pozytywny, bo niwelujący dotychczasowe negatywne stereotypy i uprzedzenia, wpływ spotkania członków grup społecznych pozostających w separacji lub konflikcie (Allport, 1954). Wielość obwarowań dotyczących cech kontaktu może tłumaczyć rozbieżność w zakresie uzyskanych wyników. Niejasne jest już to, jak rozumieć ów kontakt: czy dla pojawienia się oczekiwanych zmian wystarczy krótka interakcja, czy wymagana jest raczej trwająca w czasie, pogłębiona psychologicznie współobecność? Dodatkowo trzeba zadbać o szczególne warunki pozytywnego co do efektu kontaktu, do których zalicza się: współzależność, wspólny nadrzędny cel, jednakowy status kontaktujących się osób, nieformalne związki osobiste, odkrycie błędu swoich dotychczasowych przekonań oraz społeczne normy akceptacji innych (Aronson, Wilson i Akert, 1997), a także międzygrupowy, nie zaś interpersonalny charakter tego kontaktu (Hewstone, 1999). Pewne praktyki społeczne w rodzaju międzynarodowej współpracy naukowej czy programów tzw. wymiany studentów (Erasmus, Sokrates) świadczą o rozumieniu pozytywnej dla relacji społecznych roli kontaktu spełniającego powyższe warunki. Działać może także codzienny, niezinstytucjonalizowany kontakt związany z pracą czy mieszkaniem na bliskich, lecz już zagranicznych terenach, możliwością kupowania atrakcyjnych towarów czy uprawiania sportów w lepszych warunkach, co może wyjaśniać pozytywny stosunek do Niemców czy całej Unii Europejskiej ustalony w badaniach Krzysztofa Zagórskiego (2003). Nie tylko Polacy (i Niemcy) korzystają z udogodnień spowodowanych otwarciem granic, na co wskazują badania przeprowadzone w Słubicach i we Frankfurcie nad Odrą. Badania innych bliźniaczych miast: hiszpańskiego Els Limits i francuskiego Le Perthus wskazują z jednej strony negatywy tej sytuacji, które mogą zmieniać obraz sąsiadów (wzrost bezrobocia czy przemyt narkotyków i większe niż wcześniej poczucie niebezpieczeństwa), lecz z drugiej mieszkańcy obu miejscowości cenią rozwój budownictwa i sieci handlowej, możliwość robienia korzystnych zakupów, ale nade wszystko wolność swobodnego przemieszczania się (choć Hiszpanie odwiedzali stronę francuską rzadko, a 5\% z nich - nigdy!) (Markuszewska, Tanskanen i Subirós, 2016). Trzeba jednocześnie zgodzić się z twierdzeniem Pawła Boskiego, że „hipoteza kontaktu nigdy nie przybrała wersji kulturowej” (Boski, 2009, s. 501), co wyraża się także w stałej słabości programów treningów ukierunkowanych na zmiany w relacjach międzykulturowych. 
Dobrym podejściem służącym zrozumieniu ewentualnego wpływu pogranicza na postawy jego mieszkańców są badania uwzględniające porównania z mieszkańcami obszarów centralnych (choćby przywołane wcześniej badania Zielińskiej (2007)). Wyniki badań Krystyny Janickiej i Michała Bojanowskiego (2006) wskazują na to, że choć różnice w postawach wobec imigrantów nie są zbyt duże, to jednak tworzą pewien wzór. Mieszkańcy województw wschodnich (podlaskie, lubelskie i podkarpackie) w porównaniu z mieszkańcami innych regionów Polski cechują się najniższym poziomem deklarowanej ogólnej tolerancji wobec obcych, najniższym stopniem otwartości i skłonności do integracji oraz dość wysokim poziomem poczucia zagrożenia ekonomicznego. Ta ostatnia postawa występuje też, i to w większym nasileniu, wśród mieszkańców województw centralnych (kujawsko-pomorskie i łódzkie), którzy jednocześnie deklarują wysoką otwartość i skłonność do integracji. Jeszcze innych rezultatów dostarczają badania Zagórskiego (2003), na podstawie których można stwierdzić, że mieszkańcy polskich pograniczy (zachodniego, południowego i wschodniego) mają albo zdecydowanie lepszy, albo zdecydowanie gorszy stosunek do sąsiednich narodów niż mieszkańcy centrum. Hipoteza o bardziej pozytywnym stosunku mieszkańców pograniczy wobec sąsiadów w porównaniu do postaw wobec nich mieszkańców regionów centralnych sprawdziła się tylko w odniesieniu do Niemców i Słowaków. Bezpośrednie sąsiedztwo nie wpływa w istotny sposób na stosunek do Czechów, Ukraińców i Białorusinów, natomiast stosunek do Litwinów i Rosjan jest wyraźnie gorszy niż ten, który demonstrują mieszkańcy województw centralnych. Jednocześnie lepszy stosunek wobec Unii Europejskiej obserwuje się na sąsiadujących z nią terenach, choć miejsce zamieszkania wywiera wpływ słabszy niż poziom wykształcenia, skala zainteresowania polityką oraz wielkość miejscowości zamieszkania.

\section{Podsumowanie}

Przegląd wybranych badań dotyczących specyfiki życia na pograniczu terytorialnym wskazuje na trudności w niepodważalnym zweryfikowaniu hipotezy na temat związku tego miejsca zamieszkania ze zjawiskami psychologicznymi i społecznymi, które można tam zaobserwować. Może źle postawiony jest sam problem? Miejsce jako przedmiot badań jest jednak coraz bardziej obecne w naukach społecznych. O zainteresowaniu nim świadczy stosowanie takich terminów, jak: „przestrzeń narracyjna”, „geografia tożsamości”, „mapowanie tożsamości”, „suwerenność bez terytorialności” 
czy „zanikanie i wzmacnianie granic” (Nikiforova, 2010). W psychologii miejsca, którą można uznać za wydzielony fragment psychologii środowiskowej charakteryzujący się dużą dozą orientacji fenomenologicznej, „miejsce”, które różni się od pokrewnych pojęć „przestrzeni” czy „lokalizacji” tym, że jest definiowane przez znaczenie, a zatem treść, jest ważnym czynnikiem określającym działania człowieka. Jak pisze Lewicka (2012, s. 11), „informacje uzyskane z sondaży [...] stają się zatem informacjami o miejscu tylko wtedy, gdy przekładają się na konkretne treści i znaczenia psychologiczne: na opis konkretnych kościołów lub placów w mieście, na treść ludzkich spostrzeżeń, przekonań, pamięci i wyobraźni. I to właśnie owa treść lub znaczenie powodują, że materia staje się miejscem i zaczyna odgrywać rolę niezależnego gracza w zachowaniach społecznych ludzi, określając je, stymulując lub ograniczając”.

W nawiązaniu do tradycyjnego, „przestrzennego” rozumienia pogranicza można wskazać na codzienne choćby obserwacje, które sugerują psychologiczne znaczenie miejsca zamieszkania: oddalenie od centrów decyzyjnych może sprzyjać doświadczeniu prowincjonalizmu (kresy), poczuciu niższej wartości, słabszemu przywiązaniu do terenu, na którym się żyje, może też osłabiać kontakty społeczne z osobami z centrum oraz wywoływać tendencje do migracji. Nie sposób także pominąć dokonań socjologów, pedagogów i badaczy kultury, którzy dostarczyli licznych koncepcji, hipotez i badań dotyczących różnych pograniczy. To szczególne terytorium, które trwale zamieszkują przedstawiciele zbiorowości etnicznych posiadający odmienne, odrębne w świadomości systemy kulturowe, cechujący się identyfikacją z miejscem i specyficzną tożsamością, powinno determinować określone kontakty społeczne (międzygrupowe i interpersonalne) oraz wpływać na procesy psychiczne i zachowanie się ludzi. Ważne jest badanie tej przestrzeni jako kontekstu tworzenia się i trwania wspólnot, poznawanie jego społecznego i kulturowego wymiaru, odmiennych systemów wartości i skryptów zachowania, procesu wymiany w tym zakresie oraz charakteru relacji społecznych (w ramach grupy własnej i z członkami grupy obcej).

Za niekonkluzywność badań nad pograniczem, niewyraźność oczekiwanego „efektu” pogranicza związanego z możliwym wpływem pogranicza na jego mieszkańców odpowiada zatem bardziej niż brak uzasadnienia dla badań ich dotychczasowa metodologia. Gołdyka, jak wspomniano wcześniej, podkreśla dwojakiego rodzaju niedostatki w tym zakresie: (1) ograniczona liczba badań porównawczych prowadzonych na pograniczach, praktycznie brak jednoczesnych badań porównawczych i podłużnych; (2) nieadekwatność narzędzi pomiaru efektu pogranicza (Gołdyka, 2016, s. 27). 
Rozwijając te uwagi, można dodać, że w kolejnych programach badawczych konieczne jest uwzględnienie różnorodności pograniczy. Są pogranicza nowe, na przykład polsko-niemieckie powstałe w wyniku wyznaczenia granic po II wojnie światowej, i stare (polsko-słowackie), pogranicza etniczne i kulturowe bliskich (polsko-białoruskie) i odległych (polsko-rosyjskie) społeczności. W każdej sytuacji działa kontekst ukształtowany przez czynniki historyczne, kulturowe, ekonomiczne, społeczne, demograficzne, ideologiczne (polityczne) i prawne. W przypadku porównania różnych pograniczy (w Polsce - zachodniego, wschodniego i południowego) konieczne jest też odniesienie się do cech centrum i zamieszkujących je ludzi (Słomczyński, 2014). Ważne jest także kontrolowanie wpływu na życie na pograniczu zmiany funkcji granic: w Europie wiąże się to z utworzeniem Unii Europejskiej i zapisami z Schengen, co osłabiło ochronną funkcję granicy polsko-niemieckiej czy polsko-litewskiej, lecz wzmocniło granicę polsko-białoruską i białorusko-litewską, a także poszerzenie zakresu badań w celu ustalenia „efektu” pogranicza w krajach innych niż Polska i w regionach innych niż Europa. Potencjalnym obiektem badań jest też transgranicze, które wydobywa złożoność relacji międzynarodowych i międzykulturowych.

W badaniach pogranicza większy udział powinni mieć psychologowie, bo to oni stosują zróżnicowane i subtelne narzędzia pomiarowe przydatne także dla zrozumienia różnych cech i sposobu życia mieszkańców takich terenów. Stosowanie obserwacji uczestniczącej, kwestionariuszy oraz testów osobowości i zdolności, skal postaw, a także eksperymentów naturalnych i laboratoryjnych powinno przybliżyć zrozumienie sposobu postrzegania siebie i innych, wzajemnych ustosunkowań, zakresu i natury konfliktów społecznych (stereotypy i uprzedzenia), preferencji aksjologicznych czy ideologii. Basia Nikiforova (2010) proponuje stosowanie metody wolnej narracji o życiu na granicy, aby uzyskać dane pozwalające stworzyć ogólny obraz mieszkańców pogranicza, ich szczególnych cech i stylu życia.

Koncentracja na pograniczu terytorialnym nie powinna eliminować zainteresowania pograniczem społeczno-symbolicznym, a więc innym niż wcześniej definiowane pogranicze terytorialne. Babiński wskazuje, że pogranicze stanowi bardziej przestrzeń kulturowo-symboliczną niż fizyczną i może występować także na styku między zbiorowościami niezwiązanymi z konkretnymi terytoriami. Idąc dalej, twierdzi, że w wyniku działania takich czynników, jak globalizacja, aktywność środowisk regionalnych czy przekształcenia indywidualnych tożsamości „współczesne pogranicza [...] mają często wyłącznie subiektywny i symboliczny charakter, gdyż często nie ma tam nawet różnic językowych” (Babiński, 1994, s. 20). Na pierwszy plan 
wysuwa się więc tutaj społeczny aspekt pogranicza, znosząc jego terytorialność. W takim rozumieniu pogranicze nie spełnia funkcji odgradzającej lub dzielącej, ale jest sferą przejściową między grupami (Romanowicz, 2007). Szczególną rolę odgrywają kontakty między zamieszkującymi je ludźmi. Różnice kulturowe między osobami i grupami społecznymi mogą być rozmaite: poczynając od niewielkich (studia młodego człowieka pochodzącego ze wsi w dużym ośrodku akademickim, dojazdy do pracy w mieście - kategoria tzw. słoików), po istotne (kontakt imigrantów z mniej lub bardziej odległych państw z autochtonami). W obu przypadkach istotne byłoby prowadzenie badań określających determinanty, przebieg i skutki kontaktów na podstawie choćby koncepcji stresu akulturacyjnego i postaw wobec akulturacji (Berry i Kim, 1988; Berry, Kim, Power, Young i Bujaki, 1989; Boski, 2010). Wszystkie te badania powinny przybliżyć ustalenie realnego wpływu pogranicza terytorialnego na życie zamieszkujących je osób, grup społecznych i wreszcie całego społeczeństwa, do którego należą, a także wskazać konglomerat korzyści rozwojowych i zagrożeń, jakie ono stwarza.

\section{Literatura}

Allport, G. W. (1954). The nature of prejudice. Reading: Addison-Wesley.

Aronson, E., Wilson, T. D., Akert, R. M. (1997). Psychologia społeczna, przeł. J. Gilewicz. Poznań: Zysk i S-ka Wydawnictwo.

Babiński, G. (1994). Pogranicze etniczne, pogranicze kulturowe, peryferie. Szkic wstępny problematyki. Pogranicze. Studia Społeczne, 4, 5-28.

Babiński, G. (2001). Pogranicza stare i nowe. Ciągłość i zmiana procesów społecznych. W: K. Krzysztofek, A. Sadowski (red.), Pogranicza etniczne w Europie. Harmonia i konflikty (ss. 69-82). Białystok: Wydawnictwo Uniwersytetu w Białymstoku.

Babiński, G. (2005). Tożsamości na pograniczach. W: E. Budakowska (red.), Tożsamość bez granic. Współczesne wyzwania (ss. 99-117). Warszawa: Wydawnictwa Uniwersytetu Warszawskiego.

Bartkowski, J. (2003). Tradycja i polityka. Wpływ tradycji kulturowych polskich regionów na współczesne zachowania społeczne i polityczne. Warszawa: Wydawnictwo Akademickie Żak.

Barwiński, M. (2017). Borderland of nations, religions and cultures - the case of Podlasie. European Spatial Research and Policy, 24 (2), 111-125.

Bauman, Z. (2002). Renaissance wars of the planetary frontierland. Theory, Culture \& Society, 19 (4), 81-90.

Berry, J. W., Kim, U. (1988). Acculturation and mental stress. W: P. R. Dasen, J. W. Berry, N. Sartorius (red.), Health and cross-cultural psychology: Toward applications (ss. 207-236). Newbury Park: Sage.

Berry, J. W., Kim, U., Power, S., Young, M., Bujaki, M. (1989). Acculturation attitudes in plural societies. International Review of Applied Psychology, 38 (2), 185-206. 
Boski, P. (2009). Kulturowe ramy zachowań społecznych. Podręcznik psychologii międzykulturowej. Warszawa: Wydawnictwo Naukowe PWN.

Boski, P. (2010). Psychologia migracji i akulturacji w społeczeństwie wielokulturowym. W: H. Grzymała-Moszczyńska, A. Kwiatkowska, J. Roszak (red.), Drogi i bezdroża: Migracje Polaków w Unii Europejskiej po 1 maja 2004 roku - analiza psychologiczno-socjologiczna. Kraków: Zakład Wydawniczy Nomos.

Chlebowczyk, J. (1983). O prawie do bytu małych i młodych narodów. Kwestia narodowa i procesy narodotwórcze we wschodniej Europie Środkowej w dobie kapitalizmu (od schyłku XVIIII wieku do poczq̨tków XX wieku). Warszawa: PWN.

Deleuze, G., Guattari, F. (1994). What is philosophy? London: Verso.

Dębicki, M., Doliński, W. (2011). Stereotyp mieszkańca Görlitz w oczach zgorzelczan w oparciu o analizę wybranych zmiennych społeczno-demograficznych. W: K. Dolińska, N. Niedźwiecka-Iwańczak (red.), Zgorzelec jako miasto pograniczne w opiniach jego mieszkańców (ss. 105-146). Wrocław: Instytut Socjologii Uniwersytetu Wrocławskiego.

Domagała, B. (1996). Mniejszość niemiecka na Warmii i Mazurach: rodowód kultury, organizacja, tożsamość. Rozprawy i Materiały Ośrodka Badań Naukowych im. Wojciecha Kętrzyńskiego w Olsztynie, Olsztyn.

Goldstein, E. G. (2003). Zaburzenia z pogranicza. Modele kliniczne i techniki terapeutyczne, przeł. P. Kołyszko. Gdańsk: Gdańskie Wydawnictwo Psychologiczne.

Golka, M. (1999). Pogranicza - transgraniczność - transkulturowość. W: L. Gołdyka (red.), Transgraniczność w perspektywie socjologicznej - kontynuacje (ss. 13-26). Zielona Góra: Instytut Socjologii WSP w Zielonej Górze.

Golka, M. (2004). Tożsamość granic - granice tożsamości. W: Z. Drozdowicz (red.), Europa w nowych granicach czy Europa bez granic? (ss. 13-26). Poznań: Wydawnictwo Humaniora.

Gołdyka, L. (2016). Uwagi o „efekcie” pogranicza, W: J. Miluska (red.), Psychologia społeczno-kulturowego pogranicza. Wstęp do koncepcji i badań (ss. 15-30). Szczecin: Wydawnictwo Naukowe Wydziału Humanistycznego US Minerwa.

Górkiewicz, M., Kroplewski, Z. (2016). Poczucie przynależności do miejsca na pograniczu polsko-niemieckim na przykładzie mieszkańców Szczecina. W: J. Miluska (red.), Psychologia społeczno-kulturowego pogranicza. Wstęp do koncepcji i badań (ss. 199-219). Szczecin: Wydawnictwo Naukowe Wydziału Humanistycznego US Minerwa.

Hewstone, M. (1999). Kategoryzacja i kontakt. Zmiana stosunków międzygrupowych w ujęciu psychologii społecznej. W: C. N. Macrae, C. Stangor, M. Hewstone (red.), Stereotypy i uprzedzenia. Najnowsze ujęcie, przeł. M. Majchrzak. Gdańsk: Gdańskie Wydawnictwo Psychologiczne.

Hummon, D. M. (1992). Community attachment. Local sentiment and sense of place. W: I. Altman, S. M. Low (red.), Place attachment (ss. 253-277). New York-London: Plenum Press.

Janicka, K., Bojanowski, M. (2006). Stosunek do imigrantów i polityki imigracyjnej w Polsce; aspekt terytorialny. W: Ż. Leszkowicz-Baczyńska (red.), Transgraniczność w perspektywie socjologicznej. Nowe pogranicza? (ss. 85-99). Zielona Góra: Lubuskie Towarzystwo Naukowe.

Kłoskowska, A. (1996). Kultury narodowe u korzeni. Warszawa: PWN. 
Kowalczuk, K. (2015). Polacy o swoim przywiązaniu do miejsca zamieszkania i kraju. CBOS Komunikat z badań, 165, 1-7.

Kurcz, Z. (2008). Przedmiot socjologii pogranicza w świetle polskich doświadczeń. W: Z. Kurcz (red.), Polskie pogranicza w procesie przemian, t. 1 (ss. 19-27). Wałbrzych: Wydawnictwo Wyższej Szkoły Zarządzania i Przedsiębiorczości.

Laczko, L. S. (2005). National and local attachment in a changing world system: Evidence from an international survey. International Review of Sociology, 15, 517-528.

Leontidou, L., Donnan, H., Afouxenidas, A. (2005). Exlusion and Difference along the UE Border: Social and Cultural Markers, Spatialities and Mappings. International Journal of Urban and Regional Research, 29 (2), 389-408.

Lewicka, M. (2012). Psychologia miejsca. Warszawa: Wydawnictwo Naukowe Scholar.

Linehan, M. M. (2007). Zaburzenie osobowości z pogranicza. Terapia poznawczo-behawioralna, przeł. R. Andruszko. Kraków: Wydawnictwo UJ.

Markuszewska, I., Tanskanen, M., Subirós, J. V. (2016). Boundaries from borders: Cross-border relationships in the context of the mental perception of a borderline - experiences from Spanish-French and Polish-German border twin towns. Quaestiones Geographicae, 35 (1), 105-119.

Marzec, M. (2010). Uczestnictwo Polaków w praktykach religijnych i ich ocena roli Kościoła w życiu publicznym, Preferencje polityczne. Postawy - identyfikacje - zachowania, 1, 240-253.

Miluska, J. (2007). Autostereotyp narodowy i tożsamość narodowa - związki. Człowiek i Społeczeństwo, 27, 11-30.

Mironowicz, E. (1992). Świadomość narodowa społeczności prawosławnej Białostocczyzny. Zeszyty Naukowe Instytutu Nauk Politycznych UW, 17, 109-142.

Nikiforova, B. (2010). Transforming borders functions in the Lithuanian-Polish-Belarusian borderland. Limes, 3 (2), 124-132.

Nikitorowicz, J. (1995). Pogranicze - tożsamość - edukacja międzykulturowa. Białystok: Wydawnictwo Trans Humana.

Nikitorowicz, J. (2003). Typy tożsamości człowieka w społeczeństwie zróżnicowanym kulturowo. Chowanna, 1, 50-66.

Nikitorowicz, J. (2016). Znamienność (swoistość) tożsamości człowieka pogranicza. W: J. Miluska (red.), Psychologia społeczno-kulturowego pogranicza. Wstęp do koncepcji i badań (ss. 31-42). Szczecin: Wydawnictwo Naukowe Wydziału Humanistycznego US Minerwa.

Opioła, W. (2014). Pogranicze jako przestrzeń konfliktów. Rola misji ONZ w stabilizacji regionów pogranicznych. W: B. Maziarz (red.), Polskie misje wojskowe. Ujęcie interdyscyplinarne (ss. 21-25). Toruń: Wydawnictwo Adam Marszałek.

Plit, F. (2014). Podlasie - the landscape of cultural borderland, and not of the boundary. Dissertation of Cultural Landscape Commission, 23, 165-176.

Raciborski, J. (1997). Polskie wybory: zachowania wyborcze społeczeństwa polskiego w latach 1989-1995. Warszawa: Wydawnictwo Naukowe Scholar.

Romanowicz, W. (2007). Pogranicze jako przedmiot badań społecznych. Rozprawy Naukowe, 1, 87-97.

Sadowski, A. (1992). Pogranicze. Zarys problematyki. W: A. Sadowski (red.), Pogranicze: Studia Społeczne, t. 1 (ss. 5-7). Białystok: Uniwersytet Warszawski - Filia w Białymstoku, Wydawnictwo Filii w Białymstoku. 
Sadowski, A. (1995). Socjologia pogranicza. W: Ludzie i instytucje. Stawanie się ładu społecznego. Pamiętnik IX Ogólnopolskiego Zjazdu Socjologicznego, t. 2. Lublin: Wydawnictwo UMCS.

Sadowski, A. (2008a). Pogranicze - pograniczność - tożsamość pograniczna. Pogranicze. Studia Społeczne, 14, 17-29.

Sadowski, A. (2008b). The process of the construction of the national identities on the Polish-Lithuanian-Belarusian borderland. Limes, 1 (1), 46-54.

Sakson, A. (1996). Procesy integracji i dezintegracji społecznej na Ziemiach Zachodnich i Północnych Polski po 1945 roku. W: A. Sakson (red.), Pomorze - trudna ojczyzna? Kształtowanie się nowej tożsamości 1945-1995 (ss. 131-154). Poznań: Instytut Zachodni.

Sakson, A. (2003). Stosunek mieszkańców zachodniego pogranicza Polski do wykupu ziemi przez Niemców. W: M. Zielińska (red.), Transgraniczność w perspektywie socjologicznej. Teorie, studia, interpretacje, t. 1 (ss. 439-449). Zielona Góra: Lubuskie Towarzystwo Naukowe.

Słomczyński, K. M. (2014). Empiryczne analizy porównawcze a badania pogranicza. W: M. Zielińska, B. Trzop (red.), Transgraniczność w perspektywie socjologicznej. Pogranicza i centra współczesnej Europy (ss. 87-100). Zielona Góra: Lubuskie Towarzystwo Naukowe.

Stopa, M. (2008). „My” lokalne - „my” regionalne. Granice społecznych światów mieszkańców województwa podkarpackiego. Pogranicze. Studia Społeczne, 14, 111-126.

Szczepański, M. S., Śliz, A. (2010). Dylematy regionalnej tożsamości. Przypadek Górnego Ślq̨ska, s. 1-28, http://regionalneobserwatoriumkultury.pl, dostęp: 3.07.2018.

Titarenko, L. (2009). Belarus: A borderland civilization or civilization outskirts? Sociological reflection. Limes, 2 (1), 64-81.

Turska-Kawa, A. (2011). Wybory samorządowe w świadomości społecznej - postawy, zaangażowanie, percepcja. W: M. Kolczyński, W. Wojtasik (red.), Wybory samorzq̨dowe 2010 (ss. 27-42). Katowice: Wydawnictwo Remar.

Zagórski, K. (2003). Stosunek do sąsiednich narodów i integracji europejskiej na pograniczu i w pozostałych regionach kraju. W: M. Zielińska (red.), Transgraniczność w perspektywie socjologicznej. Teorie, studia, interpretacje, t. 1 (ss. 161-175). Zielona Góra: Lubuskie Towarzystwo Naukowe.

Zielińska, M. (2007). Pogranicze i centrum. Wybrane problemy analiz porównawczych w badaniach sondażowych. Przegląd Socjologiczny, 56 (1), 255-265.

Zielonka, J. (2018). Kontrrewolucja. Liberalna Europa w odwrocie. Warszawa: Wydawnictwo Naukowe PWN. 